\title{
Town ecology: for the land of towns and villages
}

\author{
Richard T. T. Forman
}

Received: 4 August 2019/Accepted: 14 August 2019/Published online: 21 August 2019

(C) Springer Nature B.V. 2019

An impressive body of ecological principles has emerged for forests, grasslands, crops, deserts, streams, bogs, even cities. This accomplishment robustly serves both nature and people. Yet have we missed a giant among us? What do we know about the ecology of towns, villages, and their interactions with the surrounding land?...call it town ecology (Forman 2019). Amazingly little.

I've lived and thrived in a dozen towns and villages from Maine (USA) to Honduras, yet in field research, I mainly viewed towns as places to get lunch or fuel. Now I wonder how many published data sets, or outlier points, relate to these conspicuous communities in a matrix of farmland, forest, or desert.

The land peppered with towns and villages covers perhaps half the global land surface, between urban cities/suburbs and remote natural land and pastureland. This vast town-and-village area is called home by nearly half the world's population. Furthermore it provides resources for us all, from food and fiber to clean water, recreation, and glorious landscapes.

Villages basically come in two forms, either linear or enclosed around a central green or other feature. In both cases the whole place is permeated by weather, water, and wildlife. Towns (e.g., from 2000 to 30,000

R. T. T. Forman $(\bowtie)$

Harvard University, Graduate School of Design,

Cambridge, MA 02138, USA

e-mail: rforman@gsd.harvard.edu population, and mainly surrounded by agricultural or natural land) however are of many types-large, small, coastal, mining, desert, tourist, on and on. Could such diverse places have a common anatomy? [Note that as a frontier subject, few statements can apply to all cases, modifiers are often used, and future research will determine confidence limits].

Do all or almost all towns have a commercial/ residential town center with a central plaza, an adjacent old residential area, a newer residential area with diverse neighborhoods, and a heterogeneous town edge? Is an adjacent zone of intensive impacts evident, perhaps two to a few kilometers wide? Does town-affected surrounding land then extend about half way to the next town? Much remains unknown. Is a town heat island negligible? How ecologically different are the neighborhoods in a town? How does the town edge, especially when containing a commercial or industrial center, function as a source and/or a filter of flows, movements, and effects?

Water is a big issue in towns. Residents tend to treasure or tolerate, rather than bury, their streams. Impervious surfaces are mainly small, with adjacent porous soil and plant cover. A fairly high watertable is common. Typically the stormwater drainage system is limited (except in hill towns), and relatively little stormwater surface runoff pours out of town. A floodprone area is usually present and familiar. Humanwaste disposal is a special challenge in towns with limited budgets. Persistent inquiry reveals a number of 
methods used by residents. Pollution problems warranting action are widespread, especially where water is used as a transport mechanism to carry wastes. Altogether, water conditions seem distinctive in towns.

Biodiversity in town may be rather rich, especially due to close-by surrounding vegetation. This provides a "species rain" of plants and animals, including specialist native species, that endlessly enter the entire town area. With a suitable watertable, limited air pollution, and often ample soil nutrients from former agriculture in residential areas, generally vegetation growth is luxuriant. Venerable trees tend to be treasured. Limited town maintenance budgets often result in considerable dead wood with holes containing wildlife. Non-native species are present though few sources exist compared with those in urban areas. Are "habitat clusters" (many small habitats together, such as a community garden/allotment or house plots in a block) effectively biodiversity hotspots in abundance across a town?

Wildlife readily enter and leave towns along stream corridors, even railway corridors, and probably also cross at particular land types just inside and just outside the town edge. Diverse soundscapes of bio-, geo-, and anthropo-phonic sounds may cluster around towns. A lone bright light on the edge of a town, village, or farmstead produces the "vacuum cleaner effect," sucking flying insects out of nearby habitats (as demonstrated in Germany). This reduces insect diversity and biomass as food for vertebrates. Mortality around the light is less on a bright moonlit night. Even a town's domestic cats living next to a natural area, and dogs on-leash or loose in nature, degrade wildlife habitat and potentially populations of conservation interest.

The preceding array of attributes markedly contrasts with those of urban areas, as well as agricultural and natural land. Towns are not simply small cities. Indeed, seemingly towns do not want to be a city, and certainly not a village.

A billion people are now added globally in 14 years, almost all in cities. Do we want a planet where everyone lives in a big city? Towns in farmland may be one of the best places for population growth. Towns with many multi-generation families and a handful of industries, rather than one dominant company, probably exhibit stability or slow growth. However, terms such as "Empty Spain", the "flyover
Midwest" of the USA, and the "dark encroaching forest" of Russia highlight a global pattern of change. The majority of villages, and perhaps towns, is shrinking in population on all continents. Town growth and shrinkage often relates to the beginningsand-ends of major employers in town. But nearby communities and distant forces may also cause population change. Town shrinkage leads to empty storefronts, as well as abandoned house plots with ecological succession and increasing biodiversity. Village shrinkage reduces human activity in surrounding land, and thus may be an effective mechanism for nature restoration (as suggested by work in Central Italy). Furthermore village shrinkage that aggregates people in towns and cities may reduce the human ecological footprint.

Typically just outside town is a conspicuous adjacent zone of concentrated effects, such as intensively managed orchards, vineyards, small fields, scattered houses (e.g., "homegardens" covered by useful plants in Indonesia), irrigation, dairy cows, and raising of chickens or pigs. Beyond this zone is the surrounding land of less-intensive yet diverse town effects. Rural road networks reduce some wildlife movement and gene flow (e.g., of amphibians in Spain). Human-constructed linear features connect us, but divide nature. Indeed large vegetation patches and green corridors in both the adjacent zone and surrounding land must play key ecological roles around a town. Consider the interactions between town and outside-town. Do flows and movements outward from a town mainly go to the adjacent zone and surrounding land, driven by human activities? Do inward flows, in contrast, come from regional/global, surrounding land, and adjacent zone sources driven by both natural and human processes?

Town effects on the surroundings of course vary by landscape type. In forestland, recreation effects are widespread and diverse, while villagers often harvest resources (e.g., wood from China's Panda Reserve). In pastureland, livestock water points are added and fencing subdivides the land. In desert, water source areas are widely degraded, though town wastewater often enhances downstream flows and biodiversity.

Could town ecology lead to better towns and better land? Imagine communities with local flood mitigation. Low-impact town transportation systems predominant. Building permits only issued after a wastewater system and other infrastructure are ready. 
Widespread solar panels on buildings. Disaster mitigations in place (e.g., Hanga Roa, Isla Pascua/Easter Island for tsunamis). Removal of low-usage roads bisecting natural areas. Reduced vacuum cleaning of flying insects by eliminating isolated bright lights. Wildlife crossing structures for roads at strategic points. Fewer herds of cattle and thus less greenhousegas production. Natural areas for health-promoting "forest bathing" (shinrin yoku in Japan) convenient to all residents. Imagine designing the busy town center for rich vegetation, less flooding, and almost no motorvehicles. Designing arch-shaped culverts for fish passage plus high-and-low water flows, thus minimizing road washouts (e.g., mega-storm Irene in and around Vermont, USA). Using simulation spatial models to optimize the arrangement, or fit, of a "town-centered region" containing towns, villages, roads, farmland, and natural land. Modeling to highlight the best and worst places for adding houses, roads, or commercial sites. Could better town environments reverse the slow shrinkage of residents?

As a novel subject, I never found an article or book on town ecology. This important subject will doubtless build from foundations in landscape ecology and geography, as well as water resources, urban ecology, road ecology, wildlife biology, agriculture, forestry, and more. Pioneering research at the beginning of a major frontier is long cited in the years ahead. In addition to diverse research, town ecology promises stimulating courses, teaching, and student learning. Residents and professionals will mold strategic plans, better towns, and better land uses-for the future land of towns and villages.

\section{Reference}

Forman RTT (2019) Towns, ecology, and the land. Cambridge University Press, New York

Publisher's Note Springer Nature remains neutral with regard to jurisdictional claims in published maps and institutional affiliations. 